\title{
Effect of benzoannulation on tautomeric preferences of 4,6-di(pyridin-2-yl)cyclohexane-1,3-dione
}

\author{
Robert Dobosz $\cdot$ Ryszard Gawinecki
}

Received: 18 March 2013 / Accepted: 30 April 2013 /Published online: 18 May 2013

(C) The Author(s) 2013. This article is published with open access at Springerlink.com

\begin{abstract}
Density functional theory (DFT) calculations at the B3LYP/6-311+G(d,p) level show that 4,6di(pyridin-2-yl)cyclohexane-1,3-dione is a labile compound. On the other hand, its dienolimine tautomer (4,6-di(pyridin-2-yl)cyclohaxa-1,3-diene-1,3-diol) seems stable enough to be present in vacuum. Alternatively the equilibriated species are (i) dienolimine and enolimine-enaminone ((6Z)-3-hydroxy-6-(pyridin-2(1H)ylidene)-4-(pyridine-2-yl)cyclohex-3-enone) or (ii) dienolimine, enolimine-enaminone and dienaminone ((4Z,6Z)-4,6-di(pyridin-2(1H)-ylidene)cyclohexane-1,3dione). Benzoannulation of the pyridine ring at position 5,6 was found to increase the contribution of the tautomers which contain the enaminone moiety. Energies of the transition states between the stable tautomers were also calculated in order to estimate activation energy of the proton transfer. Values of the geometry based harmonic oscillator model of aromaticity (HOMA) index and Laplacian of the electron density in the hydrogen bond critical point (based on quantum theory of atom in molecules) shows that the enaminone moiety in the tautomers studied are stabilized by stronger intramolecular hydrogen bond than this present in the enolimine moiety.
\end{abstract}

Electronic supplementary material The online version of this article (doi:10.1007/s00894-013-1874-0) contains supplementary material, which is available to authorized users.

R. Dobosz $(\bowtie) \cdot$ R. Gawinecki

Department of Chemistry, University of Technology and Life

Sciences, Seminaryjna 3,

85-326 Bydgoszcz, Poland

e-mail: robertd@utp.edu.pl
Keywords Benzoannulation · DFT · 1,3-Diketones · Pyridines $\cdot$ Tautomerizm $\cdot$ Transition states

\section{Introduction}

1,3-Dicarbonyl compounds are generally in equilibrium with the respective ketoenols [1]. On the other hand, their pyridin-2-yl derivatives equilibrate with the respective enolimine and enaminone tautomers [2-4]. Except the $\beta$-diketo species, all other forms mentioned are stabilized by the intramolecular hydrogen bonds and by the resonance [1]. Quantum-chemical calculations confirm these tautomers to be energetically preferred [2-4]. 4,6Di(pyridin-2-yl)cyclohexane-1,3-dione (1, Scheme 1), its mono, 4-(pyridin-2-yl)-6-(quinolin-2-yl)cyclohexane-1,3dione (2), and dibenzo, 4,6-di(quinolin-2-yl)cyclohexane1,3-dione (3), derivatives are other compounds of that type being of interest to us from the tautomeric point of view. Since the 3-hydroxycyclohexanone moiety present in their molecules does not allow the respective ketoenol tautomers to be stabilized by the intramolecular hydrogen bond, the number of possible products of proton transfer is not as high as for their acyclic analogues. The goal of the present paper is to show the tautomeric preferences in such special systems.

Although compounds 1-3 are not known, their properties seem worthy to be studied in order to draw general conclusions concerning the effect of structure on complex tautomeric equilibria in pyridin-2-yl derivatives of $\beta$-diketones [2-4]. Such a phenomenon plays a vital role in many important chemical and biological processes. For example, double proton transfer occurs in DNA base pairs such as the adenine- 
<smiles>[R]c1ccc(C2CC(c3ccc([R])c([R])n3)C(=O)CC2=O)nc1[R]</smiles>

Scheme 1 The formula of 4,6-di(pyridin-2-yl)cyclohexane-1,3diones. $\mathrm{R}^{1} / \mathrm{R}^{2}$ and $\mathrm{R}^{1} / \mathrm{R}^{2}=\mathrm{H} / \mathrm{H}$ and $\mathrm{H} / \mathrm{H}(\mathbf{1}), \mathrm{H} / \mathrm{H}$ and benzo (2), benzo and benzo (3)

thymine base pair [5]. A wide range of enzyme reactions, including serine proteases [6,7], alcohol dehydrogenases [8], and carbonic anhydrases [9], require multiple proton transfer reactions.

\section{Computational details}

Geometry optimizations for the tautomers and transition states were performed using Gaussian 03 software package [10]. The hybrid functional B3LYP [11, 12] and 6-311+ $\mathrm{G}(\mathrm{d}, \mathrm{p})$ basis set [13] were used. The vibrational frequencies were obtained to make sure that geometry is in minimum (no imaginary frequencies were found for all stable systems; one or two frequencies were negative for the transition states between two tautomers that differ by location of one or two hydrogen atoms, respectively). Calculations were performed for the isolated systems.

Equation (1) was used to evaluate the tautomeric constants (tautomeric constants for the $\mathbf{A} \rightleftharpoons \mathbf{B}$ equilibrium is defined as $\left.K_{T}=[\mathbf{B}] /[\mathbf{A}]\right)$. The Gibbs free energies $(\mathrm{G})$ are those calculated at B3LYP/6-311+G(d,p) level of theory ( $T=298.15 \mathrm{~K}, P=1 \mathrm{Atm}, \mathrm{R}-$ gas constant).

$K_{T}=e^{\frac{-\Delta G}{R T}}$

The bond lengths in the optimized tautomers were used to estimate the geometry-based aromaticity index HOMA $[14,15]$ defined in Eq. 2.
$H O M A=1-\frac{1}{n} \sum_{j=1}^{n} \alpha_{i}\left(R_{o p t, i}-R_{j}\right)^{2}$

$n$ represents the total number of bonds in the molecule, $\alpha_{i}$ is just the normalization constant (for $\mathrm{CC}, \mathrm{CO}$, and $\mathrm{CN}$ bonds $\alpha=257.7,157.38$ and 93.52 , respectively). It is fixed to give $\mathrm{HOMA}=0$ for the model non-aromatic system, e.g., Kekule benzene and HOMA=1 for the system with all bonds equal to the optimal value $R_{o p t, i}$, assumed to be realized for fully aromatic systems $\left(\mathrm{R}_{\mathrm{opt}, \mathrm{CC}}=138.8 \mathrm{pm}\right.$, $\mathrm{R}_{\mathrm{opt}, \mathrm{CN}}=133.4 \mathrm{pm}$ and $\mathrm{R}_{\mathrm{opt}, \mathrm{CO}}=126.5 \mathrm{pm}$ ).

Topological analysis of electron density was evaluated within the quantum theory of atom in molecule (QTAIM) model [16] using the B3LYP/6-311+G(d,p) wave functions. The critical points (BCP) were found for the hydrogen bonds studied. Electron density at BCP $\left(\rho_{\mathrm{BCP}}\right)$ and its Laplacian $\left(\nabla^{2} \rho_{\mathrm{BCP}}\right)$ were analyzed.

\section{Results and discussion}

The compounds studied contain three acidic hydrogen atoms $\left(\mathrm{H} 3 / 3^{\prime}\right.$ and $\left.\mathrm{H} 6\right)$ and four basic centers $\left(\mathrm{N} 1 / 1^{\prime}\right.$ and O5/5'). Due to numerous potential proton transfers in their molecules, 4,6-di(pyridin-2-yl)cyclohexane-1,3dione (1) and its dibezo derivative 3 may equilibrate with 12 different tautomers. Loss of symmetry by the molecule of the respective mono benzo derivative $\mathbf{2}$ is responsible for increase of this number to 21 . The formulas of some of these tautomers are presented in Scheme 2 (the complete set of possible tautomeric forms, as well as their absolute and relative energies can be found in Supplementary materials). As this can be seen in Table 1, the relative free Gibbs energies of these forms, with respect to the most stable form, are less than $10 \mathrm{kcal} \mathrm{mol}^{-1}$.
Scheme 2 The most stable tautomeric forms of $\mathbf{1}-\mathbf{3}$. Following abbreviations were used for the respective moieties: $\mathbf{P}$ - pyridine, $\mathbf{Q}$ - quinoline, $\mathbf{E}$ and $\mathbf{E}^{\prime}$ - 1,2-dihydropyridine (enamine), $\mathbf{K}$ - ketone, O - enol

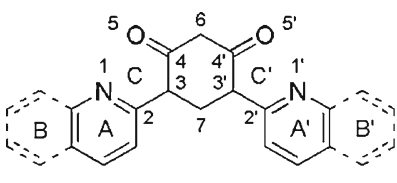

$P(Q)-K K-P(Q)$<smiles>OC1=C(c2ccc3ccccc3n2)CC(c2ccc3ccccc3n2)=C(O)C1</smiles>

$P(Q)-O O-P(Q)$<smiles>O=C1CC(O)=C(c2ccc3ccccc3n2)CC1c1ccc2ccccc2n1</smiles>

$P(Q)-O K-P(Q)$<smiles>O=C1CC(O)=C(c2ccc3ccccc3n2)C/C1=C1\C=Cc2ccccc2N1</smiles>
$P(Q)-O K-E\left(E^{\prime}\right)$<smiles>O=C1CC(=O)C(c2ccc3ccccc3n2)C/C1=C1\C=Cc2ccccc2N1</smiles>

$E\left(E^{\prime}\right)-K K-P(Q)$<smiles>O=C1CC(=O)/C(=C2/C=Cc3ccccc3N2)CC1=C1C=Cc2ccccc2N1</smiles>

$E\left(E^{\prime}\right)-K K-E\left(E^{\prime}\right)$ 
Table 1 Calculated relative Gibbs free energies $\left(\mathrm{G}_{\mathrm{rel}}\right)\left[\mathrm{kcal} \mathrm{mol}^{-1}\right]$ of the energetically most stable tautomeric forms of 4,6-di(pyridin-2yl)cyclohexane-1,3-dione (1), 4-(pyridin-2-yl)-6-(quinolin-2- yl)cyclohexane-1,3-dione (2) and 4,6-di(quinolin-2-yl)cyclohexane1,3-dione (3). Expected contributions of the respective tautomers are given in parentheses

\begin{tabular}{|c|c|c|c|c|c|}
\hline \multicolumn{2}{|l|}{1} & \multicolumn{2}{|l|}{2} & \multicolumn{2}{|l|}{3} \\
\hline Tautomers & $\mathrm{G}_{\mathrm{rel}}$ & Tautomers & $\mathrm{G}_{\text {rel }}$ & Tautomers & $\mathrm{G}_{\mathrm{rel}}$ \\
\hline P-OO-P & $0.00^{\mathrm{a}}(99 \%)$ & P-OK-E' & $0.00^{\mathrm{b}}(57 \%)$ & Q-OK-E' & $0.00^{\mathrm{c}}(38 \%)$ \\
\hline P-OK-E & $2.55(1 \%)$ & P-OO-Q & $0.17(42 \%)$ & $\mathbf{E}^{\prime}-\mathbf{K K}-\mathbf{E}^{\prime}$ & $0.04(36 \%)$ \\
\hline P-OK-P & 3.98 & Q-OK-E & 2.74 & Q-OO-Q & $0.22(26 \%)$ \\
\hline E-KK-E & 4.79 & $\mathbf{E}^{\prime}-\mathrm{KK}-\mathbf{P}$ & 3.16 & $E^{\prime}-K K-Q$ & 3.44 \\
\hline E-KK-P & 5.81 & Q-OK-P & 4.16 & Q-OK-Q & 4.39 \\
\hline \multirow[t]{4}{*}{ P-KK-P } & 6.35 & E-KK-E' & 4.25 & Q-KK-Q & 7.68 \\
\hline & & P-OK-Q & 4.35 & & \\
\hline & & E-KK-Q & 6.21 & & \\
\hline & & P-KK-Q & 6.96 & & \\
\hline
\end{tabular}

${ }^{\text {a }}$ Absolute Gibbs free energy: -878.100154 Hartree

${ }^{\mathrm{b}}$ Absolute Gibbs free energy: -1031.738160 Hartree

${ }^{\mathrm{c}}$ Absolute Gibbs free energy: -1185.375697 Hartree

Transfer of $\mathrm{H}_{3} / \mathbf{3}^{\prime}$ in the $\mathbf{P}(\mathbf{Q})-\mathbf{K K}-\mathbf{P}(\mathbf{Q})$ forms to $\mathrm{O} 5 / 5^{\prime}$ or to $\mathrm{N} 1 / 1^{\prime}$ results in formation of the enolimine, $\mathbf{P}(\mathbf{Q})-\mathbf{O}$, or enaminone, $\mathbf{E}\left(\mathbf{E}^{\prime}\right)-\mathbf{K}$, moieties, respectively, both being stabilized by the intramolecular hydrogen bonds. On the other hand, similar interaction, i.e., $\mathrm{OH}^{\cdots}{ }^{\cdots} \mathrm{O}=\mathrm{C}$, is not possible in the ketoenol moiety formed by "shifting" of H6 to the carbonyl oxygen. As a consequence, such tautomers have relatively high energies (Supplementary material) and do not contribute to the tautomeric mixture.

Among different dipyridine tautomers possible, the POO-P form was found to be energetically most stable in vacuum (Table 1). Both mono- and dibenzo annulation do not change the tautomeric preference: contributions of the respective tautomers are still high $(42 \%$ and $26 \%$, respectively). As this was expected, extension of the aromatic system in the molecule results in stabilization of the $\mathbf{E}$ moieties (Table 1).
As can be seen in Table 2, activation energies of proton transfers between the tautomers, $\mathrm{E}_{\mathrm{a}}$, are in general equal to 2.9-3.2 $\mathrm{kcal} \mathrm{mol}^{-1}$. The equilibrium between $\mathbf{P}-$ OO-P and P-OK-E is an exception: $E_{a}=4.3 \mathrm{kcal} \mathrm{mol}^{-1}$. This increased barrier to the rearrangement and low tautomeric constant, $\mathrm{K}_{\mathrm{T}}=0.01$, support exceptional character of the P-OO-P form (the tautomers are expected to contribute). Both $\mathrm{K}_{\mathrm{T}}=0.76$ and low values of the proton transfer activation energy $\left(E_{a}=2.9 \mathrm{kcal} \mathrm{mol}^{-1}\right)$ for the equilibrium between P-OO-Q and P-OK-E' (Table 2) shows that the respective proton transfer proceeds easily. As a consequence, each of these tautomers contributes significantly (Table 1). $\Delta \mathrm{G}>0$ and low value of $\mathrm{K}_{\mathrm{T}}$ (Table 2) show that proton transfer between the dibenzo annulated Q-OK-E', $\mathbf{E}^{\prime}-\mathbf{K K}-\mathbf{E}^{\prime}$ and $\mathbf{Q}-\mathbf{O O}-\mathbf{Q}$ species is quite easy. Thus, all three tautomers are expected to equilibriate between themselves. As expected, the mutual
Table 2 Calculated Gibbs free energies of the proton transfers, tautomeric constants, $\mathrm{K}_{\mathrm{T}}=[\mathbf{B}] /$ $[\mathbf{A}]$ and proton transfer activation energies $E_{a}$

\begin{tabular}{lccccc}
\hline $\mathrm{A} \rightleftharpoons \mathrm{B}$ & $\mathrm{G}_{\mathrm{A}}[$ Hartree $]$ & $\mathrm{G}_{\mathrm{B}}[$ Hartree $]$ & $\Delta \mathrm{G}\left[\mathrm{kcal} \mathrm{mol}^{-1}\right]$ & $\mathrm{K}_{\mathrm{T}}$ & $\mathrm{E}_{\mathrm{a}}\left[\mathrm{kcal} \mathrm{mol}^{-1}\right]$ \\
\hline $\mathrm{P}-\mathrm{OO}-\mathrm{P} \rightleftharpoons \mathrm{P}-\mathrm{OK}-\mathrm{E}$ & -878.100154 & -878.096091 & 2.55 & 0.01 & 4.3 \\
$\mathrm{P}-\mathrm{OK}-\mathrm{E}^{\prime} \rightleftharpoons \mathrm{P}-\mathrm{OO}-\mathrm{Q}$ & -1031.738160 & -1031.737897 & 0.17 & 0.76 & 2.9 \\
$\mathrm{Q}-\mathrm{OK}-\mathrm{E}^{\prime} \rightleftharpoons \mathrm{E}^{\prime}-\mathrm{KK}-\mathrm{E}^{\prime}$ & -1185.375697 & -1185.375641 & 0.04 & 0.94 & 3.2 \\
$\mathrm{Q}-\mathrm{OK}-\mathrm{E}^{\prime} \rightleftharpoons \mathrm{Q}-\mathrm{OO}-\mathrm{Q}$ & -1185.375697 & -1185.375347 & 0.22 & 0.69 & 2.9 \\
$\mathrm{E}^{\prime}-\mathrm{KK}-\mathrm{E}^{\prime} \rightleftharpoons \mathrm{Q}-\mathrm{OO}-\mathrm{Q}$ & -1185.375641 & -1185.375347 & 0.18 & 0.73 & 5.9 \\
\hline
\end{tabular}


<smiles></smiles>

Scheme 3 Intramoleculer hydrogen bonds bonds present in enolimines and enaminones

transformation of $\mathbf{E}^{\mathbf{\prime}}-\mathbf{K K}-\mathbf{E}^{\prime}$ and $\mathbf{Q}-\mathbf{O O}-\mathbf{Q}$ (double proton transfer $)$ is a difficult process $\left(E_{a}=5.9 \mathrm{kcal} \mathrm{mol}^{-1}\right.$, Table 2).

Hydrogen bonds in the $\mathrm{H}-\mathrm{O}-\mathrm{C}=\mathrm{C}-\mathrm{C}=\mathrm{N}$ and $\mathrm{O}=\mathrm{C}-\mathrm{C}=$ $\mathrm{C}-\mathrm{N}-\mathrm{H}$ systems (Scheme 3) enables the quasirings to be present in some tautomers discussed. The $\mathrm{NH}^{\cdots}{ }^{\cdots} \mathrm{O}$ hydrogen bond in P-OK-E is by ca 5 pm shorter than $\mathrm{OH}^{\cdots}{ }^{\cdots} \mathrm{N}$ in $\mathbf{P}-\mathbf{O K}-$ $\mathbf{P}$ and P-OO-P (Table 3). On the other hand, the later bond was found to be shorter in the mono- and dibenzo annulated tautomers.
However, the Laplacian values of electron density in the bond critical point $\left(\nabla^{2} \rho_{\mathrm{BCP}}\right)$ being equal to $0.115-0.117$ a.u. and 0.151-0.159 a.u. for the $\mathrm{OH}^{\cdots} \mathrm{N}$ and $\mathrm{NH}^{\cdots} \mathrm{O}$ bonds, respectively (Table 3 ) clearly show that the later (being present in the enaminone moieties) is stronger.

Strength of the hydrogen bonds can be also confirmed by the calculated HOMA values (Table 4). These parameters are equal to $0.39-0.44$ and $0.84-0.86$ for the quasirings stabilized by the $\mathrm{OH}^{\cdots} \mathrm{N}$ and $\mathrm{NH}^{\cdots} \mathrm{O}$ bonds, respectively. Although both of them are of resonance assisted hydrogen bond (RAHB) type [17-20], the later seems to be more strong.

Tautomeric preferences observed may be partially explained by the Clar rule [21, 22]. The HOMA values (Table 4) show that in the enolimine moiety of pyridyn2-yl derivatives only the pyridine ring is fully aromatic. On the other hand, in the enaminone moiety this ring and (quasi)ring follow the topological naphthalene-like motif
Table 3 Characteristics of two different hydrogen bonds in different tautomers studied
${ }^{\mathrm{a}}$ Distance between $\mathrm{H}$ and $\mathrm{O}$ or between $\mathrm{H}$ and $\mathrm{N}$

${ }^{b}$ Electron density in the bond critical point

${ }^{c}$ Laplacian of electron density in the bond critical point

Table 4 The HOMA values (B3LYP/6-311+G(d,p)) for the (quasi)rings present in different tautomers studied (for the ring symbols see Scheme 2)

\begin{tabular}{|c|c|c|c|c|}
\hline Tautomer & Hydrogen bond & $\mathrm{d}_{\mathrm{H} \ldots \mathrm{O}}$ or $\mathrm{d}_{\mathrm{H} \ldots \mathrm{N}}{ }^{\mathrm{a}}[\mathrm{pm}]$ & $\rho_{\mathrm{BCP}}{ }^{\mathrm{b}}$ [a.u. $]$ & $\nabla^{2} \rho_{\mathrm{BCP}}{ }^{\mathrm{c}}$ [a.u.] \\
\hline \multirow[t]{2}{*}{ P-OO-P } & $\mathrm{OH}^{\cdots} \mathrm{N}$ & 165.8 & 0.061 & 0.116 \\
\hline & $\mathrm{OH}^{\cdots} \mathrm{N}$ & 165.8 & 0.061 & 0.116 \\
\hline \multirow[t]{2}{*}{ P-OK-E } & $\mathrm{OH}^{\cdots} \mathrm{N}$ & 165.8 & 0.061 & 0.117 \\
\hline & $\mathrm{NH}^{\cdots} \mathrm{O}$ & 160.4 & 0.063 & 0.159 \\
\hline \multirow[t]{2}{*}{ P-OO-Q } & $\mathrm{OH}^{\cdots \cdots} \mathrm{N}$ & 165.4 & 0.061 & 0.116 \\
\hline & $\mathrm{OH}^{\cdots \cdots} \mathrm{N}$ & 163.5 & 0.064 & 0.115 \\
\hline \multirow[t]{2}{*}{ P-OK-E' } & $\mathrm{OH}^{\cdots \cdots} \mathrm{N}$ & 165.4 & 0.061 & 0.117 \\
\hline & $\mathrm{NH}^{\cdots \cdots} \mathrm{O}$ & 166.3 & 0.054 & 0.156 \\
\hline \multirow[t]{2}{*}{ Q-OK-E' } & $\mathrm{OH}^{\cdots \cdots} \mathrm{N}$ & 163.8 & 0.064 & 0.115 \\
\hline & $\mathrm{NH}^{\cdots \cdots} \mathrm{O}$ & 166.5 & 0.054 & 0.156 \\
\hline \multirow[t]{2}{*}{$\mathrm{E}^{\prime}-\mathrm{KK}-\mathrm{E}^{\prime}$} & $\mathrm{NH}^{\cdots \cdots} \mathrm{O}$ & 165.5 & 0.050 & 0.151 \\
\hline & $\mathrm{NH}^{\cdots \cdots} \mathrm{O}$ & 165.5 & 0.050 & 0.151 \\
\hline \multirow[t]{2}{*}{ Q-OO-Q } & $\mathrm{OH}^{\cdots \cdots} \mathrm{N}$ & 163.6 & 0.064 & 0.115 \\
\hline & $\mathrm{OH}^{\cdots}{ }^{\cdots} \mathrm{N}$ & 163.6 & 0.064 & 0.115 \\
\hline
\end{tabular}

\begin{tabular}{lcccccc}
\hline Tautomer & HOMA A & HOMA B & HOMA C & HOMA A $^{\prime}$ & HOMA B' & HOMA C' $^{\prime}$ \\
\hline P-OO-P & 0.96 & - & 0.39 & 0.96 & - & 0.39 \\
P-OK-E & 0.96 & - & 0.39 & 0.83 & - & 0.86 \\
P-OO-Q & 0.96 & - & 0.39 & 0.78 & 0.83 & 0.44 \\
P-OK-E' & 0.96 & - & 0.39 & 0.67 & 0.92 & 0.85 \\
Q-OK-E' & 0.78 & 0.83 & 0.43 & 0.67 & 0.92 & 0.85 \\
E'-KK-E' $^{\prime}$ & 0.67 & 0.92 & 0.84 & 0.67 & 0.92 & 0.84 \\
Q-OO-Q & 0.78 & 0.83 & 0.43 & 0.78 & 0.83 & 0.43 \\
\hline
\end{tabular}


Scheme 4 Graphical illustration of the Clar rule for the studied

with migration of the Clar sextet to the $\mathrm{A}^{\prime}$ and $\mathrm{C}^{\prime}$ rings (Scheme 4). The same motif can be seen for the $A\left(A^{\prime}\right)$ and $\mathrm{B}\left(\mathrm{B}^{\prime}\right)$ rings in the enolimine moieties of quinolin-2-yl derivatives. On the other hand, the (quasi)rings $\mathrm{B}\left(\mathrm{B}^{\prime}\right)$, $\mathrm{A}\left(\mathrm{A}^{\prime}\right)$ and $\mathrm{C}\left(\mathrm{C}^{\prime}\right)$ in the respective enaminone tautomers follow the phenanthrene-like motif with the empty inner ring $\mathrm{A}\left(\mathrm{A}^{\prime}\right)$, fully aromatic outer ring $\mathrm{B}\left(\mathrm{B}^{\prime}\right)$ and (quasi)ring $\mathrm{C}\left(\mathrm{C}^{\prime}\right)$ (Scheme 4). Thus, one can see that there is only one $\pi$-electron sextet, i.e., this present in the pyridine ring, in the energetically preferred P-OO-P tautomer. As this was expected, benzene $\operatorname{ring}(\mathrm{s})$ change the tautomeric preferences. The enaminone P-OK-E', Q-OK-E' and $\mathbf{E}^{\prime}-\mathbf{K K}-\mathbf{E}^{\prime}$ tautomers contain two $\pi$-electron sextets assigned to the $\mathrm{A}\left(\mathrm{A}^{\prime}\right), \mathrm{B}\left(\mathrm{B}^{\prime}\right)$ and $\mathrm{C}\left(\mathrm{C}^{\prime}\right)$ (quasi)rings (in benzenoid hydrocarbons the $\pi$-electrons participating in the aromatic sextets should be assigned to the particular rings in such a way to obtain the maximum number of $\pi$-electron sextets [23]). On the other hand, in the mono- and dibenzo annulated enolimine tautomers only one $\pi$-electron sextet is assigned to the $\mathrm{A}\left(\mathrm{A}^{\prime}\right), \mathrm{B}\left(\mathrm{B}^{\prime}\right)$ and $\mathrm{C}\left(\mathrm{C}^{\prime}\right)$ (quasi)rings, and therefore contribution of these forms is low.

\section{Conclusions}

DFT studies of the proton transfer process in the 4,6di(pyridin-2-yl)cyclohexane-1,3-dione molecule shows that among its different tautomers, dienolimine (4,6di(pyridin-2-yl)cyclohexa-1,3-diene-1,3-diol) is the most stable. Mono- and dibenzoannulation of the pyridine ring(s) results in an increase of the contribution of the enaminone species. As this was supported by the<smiles></smiles><smiles>CCOCP</smiles><smiles>CCOCCC1CCc2ccccc2N1</smiles><smiles>O=C1CC2=C(CC13CC1=[N+]3Nc3ccccc3C=C1)c1ccccc1NO2</smiles>

$E^{\prime}-K K-E^{\prime}$

geometry based HOMA index and Laplacian of the electron density in hydrogen bond critical point, of two different hydrogen bonds that may stabilize the respective tautomers, i.e., $\mathrm{N}-\mathrm{H}$... O and $\mathrm{N}$...H-O, the former is stronger. The Clar rule was also found helpful in estimation of the tautomeric preferences of 4,6di(pyridin-2-yl)cyclohexane-1,3-dione and its benzologs.

Acknowledgments Polish Ministry of Science and Higher Education is gratefully acknowledged for funding to R. D. (Grant No. IP2011 010171). The authors are very much indebted to the CI TASK Gdańsk and ACK CYFRONET AGH, Kraków (MNiSW/SGI3700/UTPBydg/ 042/2007) for supply of computer time and providing programs. This research was supported in part by PL-Grid Infrastructure.

Open Access This article is distributed under the terms of the Creative Commons Attribution License which permits any use, distribution, and reproduction in any medium, provided the original author(s) and the source are credited.

\section{References}

1. Gilli G, Bertolasi V (1990) Structural chemistry. In: Rappoport Z (ed) The chemistry of enols. Wiley, Chichester, pp 713-764

2. Dobosz R, Gawinecki R (2010) DFT studies on tautomeric preferences: proton transfer in 1,5-bis(pyridin-2-yl)- and 1,5-bis(quinolin2-yl)pentane-2,4-diones. J Mol Struct (THEOCHEM) 940:119-123. doi:10.1016/j.theochem.2009.10.019

3. Dobosz R, Gawinecki R, Kanabaj A (2010) DFT studies on tautomeric preferences. Part 2: proton transfer in 1-(pyridin-2-yl)-5(quinolin-2-yl)pentane-2,4-dione. J Mol Struct (THEOCHEM) 949:57-59. doi:10.1016/j.theochem.2010.03.004

4. Dobosz R, Gawinecki R (2011) Computational note on the tautomeric preferences of 2,7-di(pyridin-2-yl)- and 2,7-di(quinolin-2yl)hexahydronaphthalene-1,8-diones. Comp Theor Chem 967:211-212. doi:10.1016/j.comptc.2011.04.014 
5. Florián J, Hrouda V, Hobza P (1994) Proton transfer in the adenine-thymine base pair. J Am Chem Soc 116:1457-1460. doi:10.1021/ja00083a034

6. Blow DM (1976) Structure and mechanism of chymotrypsin. Acc Chem Res 9:145-152. doi:10.1021/ar50100a004

7. Zundel G (1988) Proton transfer in and proton polarizability of hydrogen bonds: IR and theoretical studies regarding mechanisms in biological systems. J Mol Struct 177:43-68. doi:10.1016/00222860(88)80078-4

8. Ramaswamy S, Eklund H, Plapp BV (1994) Structures of horse liver alcohol dehydrogenase complexed with nad + and substituted benzyl alcohols. Biochemistry 33:5230-5237. doi:10.1021/ bi00183a028

9. Ren X, Tu C, Laipis PJ, Silverman DN (1995) Proton transfer by histidine 67 in site-directed mutants of human carbonic anhydrase III. Biochemistry 34:8492-8498. doi:10.1021/ bi00026a033

10. Frisch MJ, Trucks GW, Schlegel HB, Scuseria GE, Robb MA, Cheeseman JR, Montgomery JA Jr, Vreven T, Kudin KN, Burant JC, Millam JM, Iyengar SS, Tomasi J, Barone V, Mennucci B, Cossi M, Scalmani G, Rega N, Petersson GA, Nakatsuji H, Hada M, Ehara M, Toyota K, Fukuda R, Hasegawa J, Ishida M, Nakajima T, Honda Y, Kitao O, Nakai H, Klene M, Li X, Knox JE, Hratchian HP, Cross JB, Bakken V, Adamo C, Jaramillo J, Gomperts R, Stratmann RE, Yazyev O, Austin AJ, Cammi R, Pomelli C, Ochterski JW, Ayala PY, Morokuma K, Voth GA, Salvador P, Dannenberg JJ, Zakrzewski VG, Dapprich S, Daniels $\mathrm{AD}$, Strain MC, Farkas O, Malick DK, Rabuck AD, Raghavachari K, Foresman JB, Ortiz JV, Cui Q, Baboul AG, Clifford S, Cioslowski J, Stefanov BB, Liu G, Liashenko A, Piskorz P, Komaromi I, Martin RL, Fox DJ, Keith T, Al-Laham MA, Peng CY, Nanayakkara A, Challacombe M, Gill PMW, Johnson B, Chen W, Wong MW, Gonzalez C, Pople JA (2004) Gaussian 03 Revision E01. Gaussian Inc, Wallingford

11. Becke AD (1993) Density-functional thermochemistry. III. The role of exact exchange. J Chem Phys 98:5648-5652. doi:10.1063/ 1.464913
12. Lee C, Yang W, Parr RG (1988) Development of the Colle-Salvetti correlation-energy formula into a functional of the electron density. Phys Rev B 37:785-789. doi:10.1103/PhysRevB.37.785

13. Hehre WJ, Radom L, PvR S, Pople JA (1986) Ab initio molecular orbital theory. Wiley, New York

14. Krygowski TM (1993) Crystallographic studies of inter- and intramolecular interactions reflected in aromatic character of $\pi$ electron systems. J Chem Inf Comput Sci 33:70-78. doi:10.1021/ ci00011a011

15. Sobczyk L, Grabowski JS, Krygowski TM (2005) Interrelation between $\mathrm{H}$-bond and $\pi$-electron delocalization. Chem Rev 105:3513-3560. doi:10.1021/cr030083c

16. Bader RWF (1990) Atoms in molecules. A quantum theory. Oxford University Press, New York

17. Gilli G, Bellucci F, Ferretti V, Bertolasi V (1989) Evidence for resonance-assisted hydrogen bonding from crystal-structure correlations on the enol form of the $\beta$-diketone fragment. J Am Chem Soc 111:1023-1028. doi:10.1021/ja00185a035

18. Bertolasi V, Gilli P, Ferretti V, Gilli G (1991) Evidence for resonance-assisted hydrogen bonding. 2. Intercorrelation between crystal structure and spectroscopic parameters in eight intramolecularly hydrogen bonded 1,3-diaryl-1,3-propanedione enols. J Am Chem Soc 113:4917-4925. doi:10.1021/ja00013a030

19. Gilli P, Bertolasi V, Ferretti V, Gilli G (1994) Evidence for resonance-assisted hydrogen bonding. 4. Covalent nature of the strong homonuclear hydrogen bond. Study of the O-H...O system by crystal structure correlation methods. J Am Chem Soc 116:909-915. doi:10.1021/ja00082a011

20. Bertolasi V, Gilli P, Ferretti V, Gilli G (1996) Resonance-assisted O$\mathrm{H}$... O hydrogen bonding: its role in the crystalline self-recognition of $\beta$-diketone enols and its structural and IR characterization. Chem Eur J 2:925-934. doi:10.1002/chem.19960020806

21. Clar E (1964) Polycyclic hydrocarbons. Vol 1 and 2. Academic, London

22. Clar E (1972) Aromatic Sextett. Wiley, London

23. Harvey RG (1997) Polycyclic aromatic hydrocarbons. Wiley, New York 